\title{
Introducing Motherboard Components Using Virtual Reality
}

\author{
Hanife Boydak ${ }^{1 *}$, Fatma Nur Canoğlu ${ }^{2}$, Ayșe Kayhan ${ }^{3}$, Fatih Başçiftçi ${ }^{4}$ \\ ${ }^{1 *}$ Selçuk University, Faculty of Technology, Departmant of Information Technology Engineering, Konya, Turkey, (ORCID: 0000-0001-8372-5004), \\ hanifeboydak4246@gmail.com \\ ${ }^{2}$ Selçuk University, Faculty of Technology, Departmant of Information Technology Engineering, Konya, Turkey, (ORCID: 0000-0003-1357-0419), \\ fatmanurcanoglu@gmail.com \\ ${ }^{3}$ Selçuk University, Faculty of Technology, Departmant of Information Technology Engineering, Konya, Turkey, (ORCID: 0000-0002-6856-8060), \\ ayseyucel@yandex.com \\ ${ }^{4}$ Selçuk University, Faculty of Technology, Departmant of Information Technology Engineering, Konya, Turkey, (ORCID: 0000-0003-1679-7416), \\ basciftci@ selcuk.edu.tr
}

(1st International Conference on Applied Engineering and Natural Sciences ICAENS 2021, November 1-3, 2021)

(DOI: 10.31590/ejosat.993499)

ATIF/REFERENCE: Boydak H., Canoğlu F.N., Kayhan A., Başçiftçi F. (2021). Introducing Motherboard Components Using Virtual Reality Technology. European Journal of Science and Technology, (28), 157-163.

\begin{abstract}
The study aims to introduce the main component of computers, the main component of the computer, and the sockets where these components need to be installed, firstly to secondary school, high school, and university students and then to every user who installs the application by using virtual reality technology. With the online publication and use of the application, the motherboard that needs to be learned, which will be shown to the application, but not available and only photographed, is recognized and all components on the motherboard will be learned. In addition, by showing the sockets where the components need to be installed, anyone with the application will be able to easily remove and reattach all components in their computer. The application was carried out using the $3 \mathrm{DQR}$ program because it allows the visuals to be displayed and processed in 3 dimensions. In the written article, virtual reality technology will be mentioned, then 3DQR Studio software will be introduced in the application used in the application and will be finalized by explaining it with the visuals presented.
\end{abstract}

Keywords: Virtual, Reality, Technology, Education, Motherboard, Motherboard Components.

\section{Sanal Gerçeklik Teknolojisi Kullanılarak Anakart Bileşenlerinin Tanitılması}

$\ddot{O ̈ z}$

Bu çalışma, sanal gerçeklik teknolojisinden faydalanılarak öncelikle ortaokul, lise ve üniversite öğrencilerine ardından uygulamanın kurulumunu yapan her kullanıcıya bilgisayarların temel bileşeni olan anakartın, anakart üzerinde bulunan bileşenlerin ve bu bileşenlerin takılması gereken soketlerin tanıtılmasını amaçlamaktadır. Uygulanmanın çevrimiçi olarak yayınlanıp kullanılmaya başlanmasıyla birlikte elde olan anakartın yanı sıra öğrenilmeye ihtiyaç duyulan, uygulamaya gösterilecek olan fakat elde olmayan ve yalnızca fotoğrafı temin edilebilen anakart da tanınmış olup anakart üzerinde yer alan tüm bileşenlerin de öğrenilmesi sağlanacaktır. Ayrıca bileşenlerin takılması gereken soketlerin de gösterilmesiyle uygulamaya sahip olan herkes rahatlıkla bilgisayarındaki tüm bileşenleri çıkarıp tekrar yerlerine takabileceklerdir. Yapılan uygulama görsellerin 3 boyutlu olarak gösterilip işlenmesine olanak tanıması sebebiyle 3DQR programı kullanarak gerçekleştirilmiştir. Yazılmış olan yazıda da öncelikle sanal gerçeklik teknolojisinden bahsedilecek, ardından yapılan uygulamada kullanılan 3DQR Studio programı tanıtılacaktır ve son olarak yapılmış olan uygulamanın da görsellerle desteklenerek anlatılmasıyla sonlandırılacaktır.

Anahtar Kelimeler: Sanal, Gerçeklik, Teknoloji, Eğitim, Anakart, Anakart Bileşenleri. 


\section{Introduction}

Although Virtual Reality (VR) is not a real environment created by combining software and hardware specific to its application, it is a virtual environment that feels real. With the increase in the use of smartphones in our age, virtual reality, which has been delivered to more people in easier ways, is a structure that will shed light on the technological developments to be experienced in the future [1]. Although this structure is thought to be more connected with online games today, its use in different areas is also increasing. In fact, this technology is predicted to replace the widely used smartphones in the future. Considering this estimate, it is thought that the sectors where virtual reality technology will be used will become widespread in many different areas. Virtual reality technology is used in many different areas today [2]. Health, architecture, engineering, culture, tourism, entertainment sectors, and also the education sector, which has been frequently studied recently comes first among these.

While technological developments continue rapidly, the increase in the work of virtual reality technology continues at the same speed. The feeling of the accessibility of objects, experiments, environments, and times that are invisible, inaccessible in the 3-dimensional environment of virtual reality technology brings along the curiosity and desire to work with this technology. In addition, the use of virtual reality technology in the education sector has become widespread, as the interest of all individuals in the education age has increased and the sense of excitement has increased, as well as the speed of learning [3]. The application that will be described here is an application primarily made for use in the education sector. In the practice, it is aimed to teach the types of motherboards that are available or not actually accessible to middle school, high school, and university students with a real feeling. In addition to teaching motherboard types, the components on them and the ports where these components need to be installed will be offered to all users, especially students.

\section{Literature Review}

The existence of some studies similar to the application made and inspiring for the application has been observed by researching the studies and articles written in our country and the world. These articles, which were found as a result of research, primarily focused on the use of virtual reality technology in the education sector and then the assembly of motherboards. Arvin Christopher C. REYES, Neil Patrick A. Del GALLEGO, Jordan Aiko P. DEJA researchers conducted studies on Mixed Reality Guidance System for Motherboard Assembly Using Tangible Augmented Reality in 2020 [4]. Ahmet Fatih AVCI, Şakir TAŞDEMİR researchers conducted studies on the subject of Augmented and Virtual Reality and Periodic Table Teaching in 2019 [5]. Mustafa SIRAKAYA, Ebru KILIÇ ÇAKMAK worked on Effects of Augmented Reality on Student Achievement and Self-Efficacy in Vocational Education and Training in 2018 [6]. Recep ASLAN, Saffet ERDOĞAN conducted studies on Medical Education in the 21st Century: Virtual Reality, Augmented Reality, Hologram in 2017 [7]. Igor D.D. CURCIO, Anna DIPACE, Anita NORLUND worked on Virtual Realities and Education in 2016 [8]. Sirakaya (2016) carried out his studies on the use of augmented reality in applied education in order to determine the effect on the motherboard assembly time and the number of errors made by the students [9].
Table 1. Studies showing the use of virtual reality technology in the education sector and motherboard assembly

\begin{tabular}{|c|c|c|}
\hline Study Researchers & $\begin{array}{l}\text { Publication } \\
\text { Year }\end{array}$ & Subject of Study \\
\hline $\begin{array}{l}\text { Arvin Christopher C. } \\
\text { REYES, Neil Patrick A. } \\
\text { Del GALLEGO, Jordan } \\
\text { Aiko P. DEJA }\end{array}$ & 2020 & $\begin{array}{l}\text { Mixed Reality Guidance System } \\
\text { for Motherboard Assembly Using } \\
\text { Tangible Augmented Reality }\end{array}$ \\
\hline $\begin{array}{l}\text { Ahmet Fatih AVCI, Şakir } \\
\text { TAŞDEMIR }\end{array}$ & 2019 & $\begin{array}{l}\text { Periodic Table Teaching with } \\
\text { Augmented and Virtual Reality }\end{array}$ \\
\hline $\begin{array}{l}\text { Mustafa SIRAKAYA, } \\
\text { Ebru KILIÇ ÇAKMAK }\end{array}$ & 2018 & $\begin{array}{l}\text { Effects of Augmented Reality on } \\
\text { Student Achievement and Self- } \\
\text { Efficacy in Vocational Education } \\
\text { and Training }\end{array}$ \\
\hline $\begin{array}{l}\text { Recep ASLAN, Saffet } \\
\text { ERDOĞAN }\end{array}$ & 2017 & $\begin{array}{l}\text { 21. Century Medical Education, } \\
\text { Virtual Reality, Augmented } \\
\text { Reality, Hologram }\end{array}$ \\
\hline $\begin{array}{l}\text { Igor D.D. CURCİO, } \\
\text { Anna DİPACE, Anita } \\
\text { NORLUND }\end{array}$ & 2016 & Virtual Realities And Education \\
\hline Mustafa SIRAKAYA & 2016 & $\begin{array}{l}\text { The Use of Augmented Reality in } \\
\text { Applied Education: Motherboard } \\
\text { Assembly }\end{array}$ \\
\hline $\begin{array}{l}\text { Tansel TEPE, Devkan } \\
\text { KALECİ, Hakan } \\
\text { TÜZÜN } \\
\end{array}$ & 2016 & $\begin{array}{l}\text { New Trends in Educational } \\
\text { Technologies: Virtual Reality } \\
\text { Applications }\end{array}$ \\
\hline $\begin{array}{l}\text { Giles WESTERFIELD, } \\
\text { Antonija MITROVİC, } \\
\text { Mark BILLINGHURST } \\
\end{array}$ & 2015 & $\begin{array}{l}\text { Intelligent Augmented Reality } \\
\text { Training For Motherboard } \\
\text { Assembly }\end{array}$ \\
\hline $\begin{array}{l}\text { H. Hakan ÇETİNKAYA, } \\
\text { Muammer AKÇAY }\end{array}$ & 2013 & $\begin{array}{l}\text { Augmented Reality Applications } \\
\text { in Educational Environments }\end{array}$ \\
\hline $\begin{array}{l}\text { Erkan BAYRAKTAR, } \\
\text { Fatih KALELI }\end{array}$ & 2007 & $\begin{array}{l}\text { Virtual Reality and Application } \\
\text { Areas }\end{array}$ \\
\hline Şahin KARASAR & 2004 & $\begin{array}{l}\text { New Communication } \\
\text { Technologies in Education- } \\
\text { Internet and Virtual Higher } \\
\text { Education- }\end{array}$ \\
\hline $\begin{array}{l}\text { Bülent ÇAVAŞ, Pınar } \\
\text { HUYUGÜZEL ÇAVAŞ, } \\
\text { Bilge TAŞKIN CAN } \\
\end{array}$ & 2004 & Virtual Reality in Education \\
\hline Dr. Şahin KARAHİSAR & 1999 & Education on the Internet \\
\hline $\begin{array}{l}\text { K. M. BAIRD, W. } \\
\text { BARFIELD }\end{array}$ & 1999 & $\begin{array}{l}\text { Evaluating the Effectiveness of } \\
\text { Augmented Reality Displays for a } \\
\text { Manual Assembly Task }\end{array}$ \\
\hline $\begin{array}{l}\text { Yrd. Doç. Dr. Servet } \\
\text { BAYRAM }\end{array}$ & 1999 & $\begin{array}{l}\text { Virtual Reality Applications in } \\
\text { Education }\end{array}$ \\
\hline
\end{tabular}

Tepe, Kaleci, and Tuzun (2016) have conducted research on virtual reality applications with their study on new trends in educational technologies and contributed with their articles to the 10th International Computer and Instructional Technologies Symposium in the light of previous case studies in different fields [10]. Westerfield, Mitrovic, and Billinghurst (2015) studied smart augmented reality training for motherboard assembly. As a result of these studies, they came up with a prototype and observed an accuracy of $25 \%$ and a speed of $30 \%$ compared to those who did not try the prototype [11]. Çetinkaya and Akçay (2013) carried out their studies on the effect of augmented reality on teaching and learning, based on the examples of augmented reality applications used in educational environments today [12]. Bayraktar and Kaleli (2007) conducted research on virtual reality and its application areas and shared their findings on this subject through Akademik Bilişim [13]. Karasar (2004) in this study, technological developments that constitute virtual higher education were evaluated within the scope of the theory of diffusion of innovations and a model proposal that Turkey should follow was tried to be created. It is aimed to contribute to the development of a suitable model for the effects of the developments in the world on Turkey [14]. Çavaş, Huyugüzel Çavaş and Taşkın Can (2004) in the study, brief information about virtual reality was given by explaining for what purpose and how 
virtual reality is used in education [15]. Karasar (1999) in the article, explanations were made about the reflection of the internet environment and virtual reality on education. It is very important for Turkey to catch up with this revolution along with the developments in the world, this technology created by the Internet [16]. Baird and Barfield (1999) in their research, they examined how effective augmented reality screens created with wearable devices are [17]. Bayram (1999) he worked on virtual reality technology in education. In the study, the use of virtual reality technology in learning environments was evaluated as the success of today's education [18]. Studies on the aforementioned subjects are detailed in Table 1 below.

\section{Material}

The application, whose purpose is to introduce the motherboard and the components on the motherboard, was implemented using the 3DQR Studio program. Before explaining the details of the application, the program used will be explained and then the application will be detailed.

\subsection{DQR Studio Program}

It is a ready-made platform used for augmented reality applications. It is an application that outputs a QR code. This QR code can be used anywhere.

In order to use this application, it is necessary to login from the address "3dqr.de" first. As seen in Figure 1, the site is opened in German. One-click on the flag part indicated by the red arrow is enough to change the language to an appropriate language. The English language was chosen and continued in the narration.

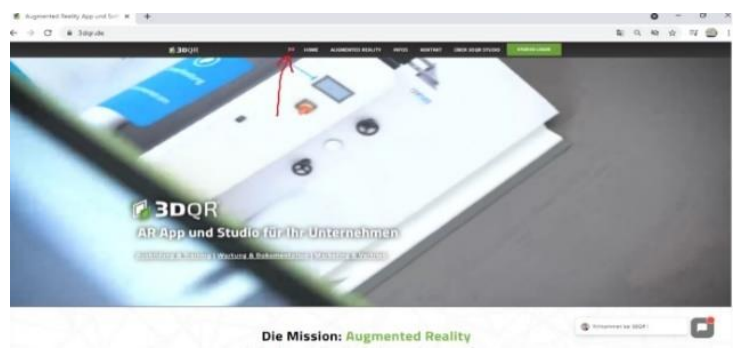

Figure 1. 3dqr.de main screen

First of all, we need to log into the system from this screen. After entering the system, it comes to the main screen. This screen is the main page of the system and the applications made are shown on this screen.

To create a $3 \mathrm{dqr}$ application, the main screen is entered and the "add new scene" button shown in Figure 2 is clicked. It is entered to the screen where the application shown in Figure 3 will be created.

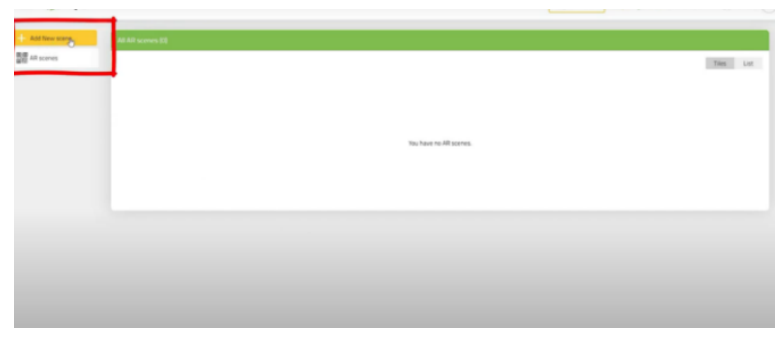

Figure 2. Creating a new application

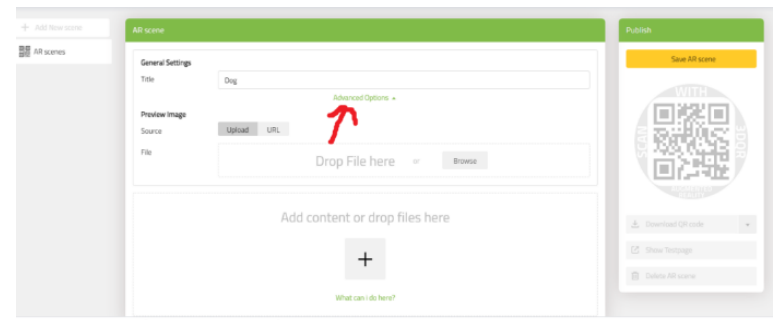

Figure 3. Application creation screen

The title of the application is entered in the "Title" section. Click on the "Advanced Option" section shown in Figure 3, and when the generated QR code is displayed on the screen, the picture to be displayed on the screen is determined. This picture can be selected from the computer or given its URL from the internet. Image articulation is performed from the computer. Click the plus $(+)$ button to add a 3 -dimensional object.

Different types of content can be added to the application as seen in Figure 4 on this screen. When video and audio additions are to be made, the loading process of the system is very slow. This is one of the disadvantages of the application. Click on the 3D model option to add a $3 \mathrm{D}$ object.

After this process, we go to the screen where we will add 3 dimensional objects. On this screen, a 3D object is added to the application. Here, you can add objects on the computer or give URLs over the internet

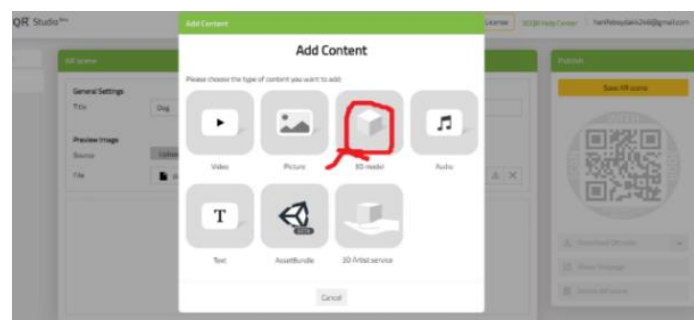

Figure 4. Adding a 3D object

After this process, we go to the screen where we will add 3dimensional objects. On this screen, a 3D object is added to the application. Here, you can add objects on the computer or give URLs over the internet.

After the necessary editing is done, the "Save AR scene" button is clicked as shown in Figure 5.

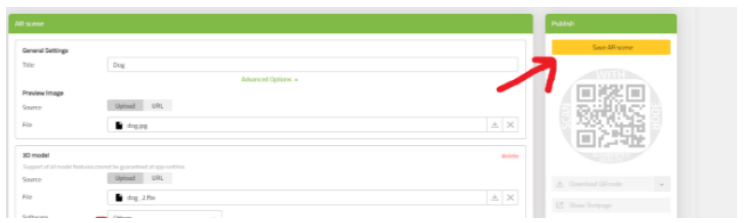

Figure 5. Save process

After the save is done, it is necessary to test the application without downloading. As shown in Figure 6, clicking on the "Show Test Page" button opens the testing screen

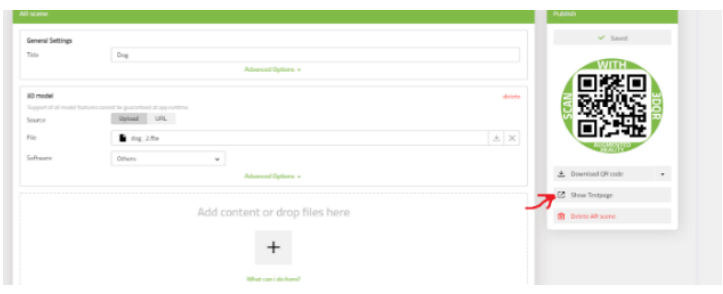

Figure 6. Testing screen 
In order for this application to be tested, the 3DQR application must be downloaded and installed on your mobile device. The process of putting the downloaded $\mathrm{QR}$ code into the picture can be done as shown in Figure 7. Then the application is run as shown in Figure 8, and as a result, it will be successfully concluded as seen in Figure 9.

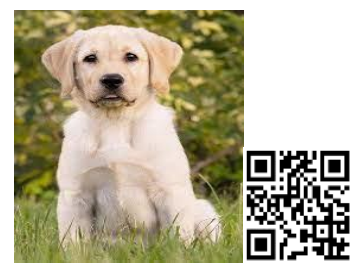

Figure 7. Adding $Q R$ code to image

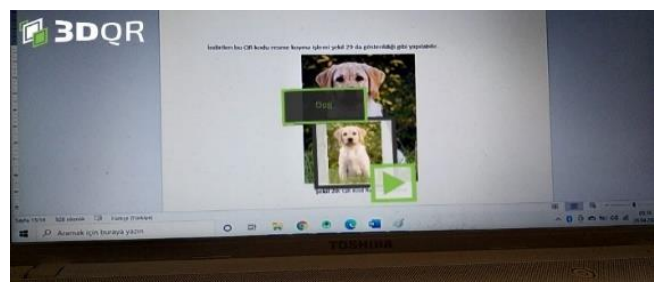

Figure 8. Running application

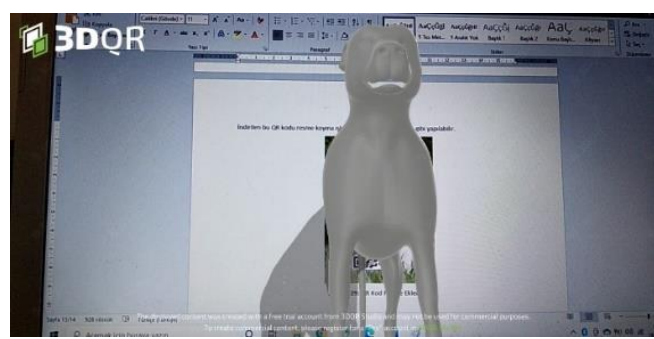

Figure 9. Operating by reading the $Q R$ code on the picture

\section{Technic}

This study aims to teach all users who will use the application, especially middle school, high school, and university students, the motherboard, motherboard components, and the ports where these components will be installed. In the construction of the application, the flow chart shown in Figure 10 was prepared by using the rough code given below. Then, the application was carried out by following the steps below in accordance with the scheme.

\section{3DQR studio program recording process}

2. Logging into the application screen

3. Creating the application

4. Loading the 3D model of the motherboard by holding the QR on the mobile device.

\section{Entering QR section materials}

6. Downloading the motherboard model

7. QR registration process

8. Observing the downloaded screen part of the QR code created in the application

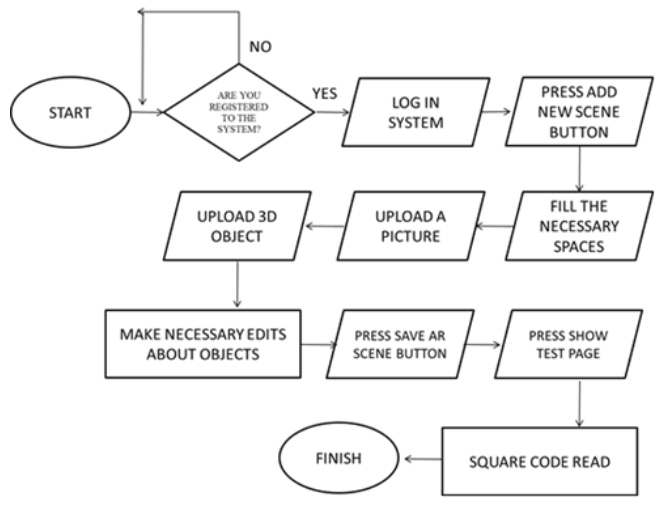

Figure 10. The flow chart followed for the construction stages of the application

Step1: 3DQR studio is an intuitive web platform for developing and managing augmented reality scenes. In order to use this application, it is necessary to login from the $3 \mathrm{DQR}$ address first. The registration image of the site is given in Figure 11 below.
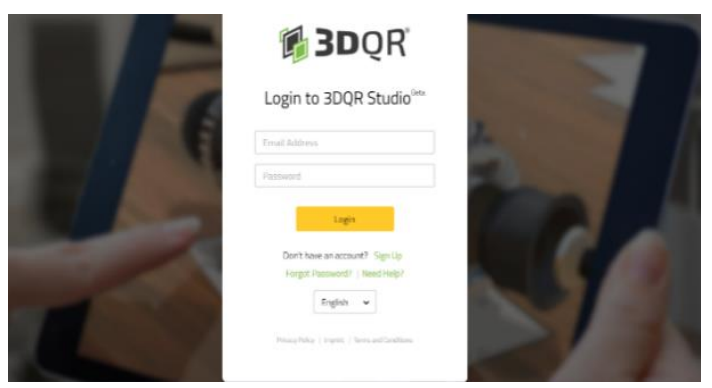

Figure 11. Record performs screen

Step2: After entering the user's name and password, the application screen is entered. The $3 \mathrm{DQR}$ studio is able to record all the operations performed on the home page of the application and provides the perfect solution for a working world where more and more data is processed and machines are becoming more and more complex. Later, when the application is entered, the screenshot shown in Figure 12 below is displayed in order to update or reuse the projects.

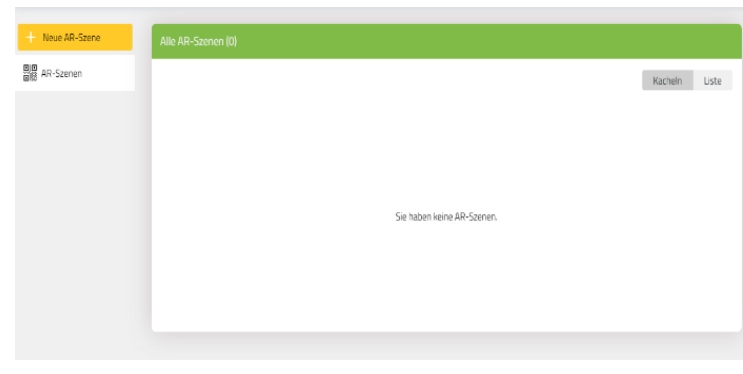

SSekil 12. Home screen of the application

In order to create virtual reality content, $3 \mathrm{DQR}$ studio enables the import of various files; 3D models support a variety of standard formats for images or videos. It provides full control over the entire development process by creating your own content with well-known 3D software such as Blender, Autodesk, Maya, or Unity3D. While we can design 3D models ourselves, formats can be added from public databases such as "Turbosquid.com" or "Paint3D", regardless of whether they are professional 3D models or free alternatives.

There are some things we need to be aware of when using virtual reality applications. For example, certain formats are 
allowed when using the 3D model in the 3DQR application. When using these and similar applications, the only thing to do before downloading is to change these formats. The $3 \mathrm{DQR}$ application we use accepts the .fbx format.

The three-dimensional model of the motherboard should be taken from the 3D software we designed or from a public database and used in a format suitable for the application. These formats are very important and it is because 3DQR technology allows .fbx format.

Step3: Creating a new QR in 3DQR technology is done from the "Add New Scene" section on the left in Figure 12. The part shown and displayed in Figure 13 is the area where we create the application.

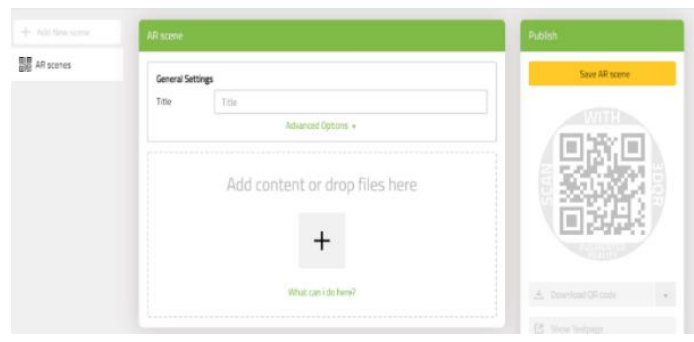

Figure 13. Application created area screen

Step4: In this application, it has been provided to generate QR by using the "advanced options" section shown in Figure 13 to display the 3D model of the motherboard on the screen. The mobile device is used for the application. The produced QR is held on the mobile device and the $3 \mathrm{D}$ model of the motherboard is displayed on the screen. In Figure 14 below, the 3D model of the motherboard has been uploaded on the computer in the "upload" section.

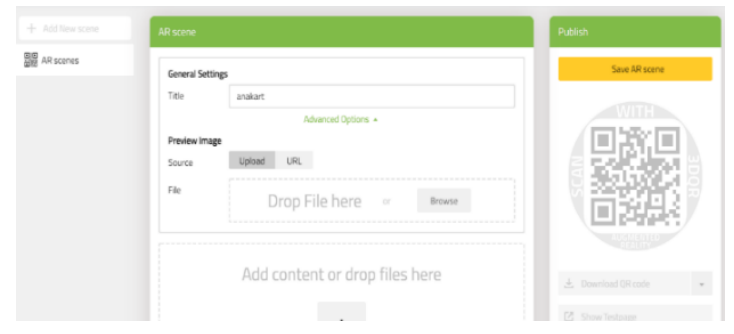

Figure 14. Image upload screen

Step5: In Figure 15, different features can be uploaded to the QR section other than the 3D model, and they can be added in materials such as video, music, pictures, and text.

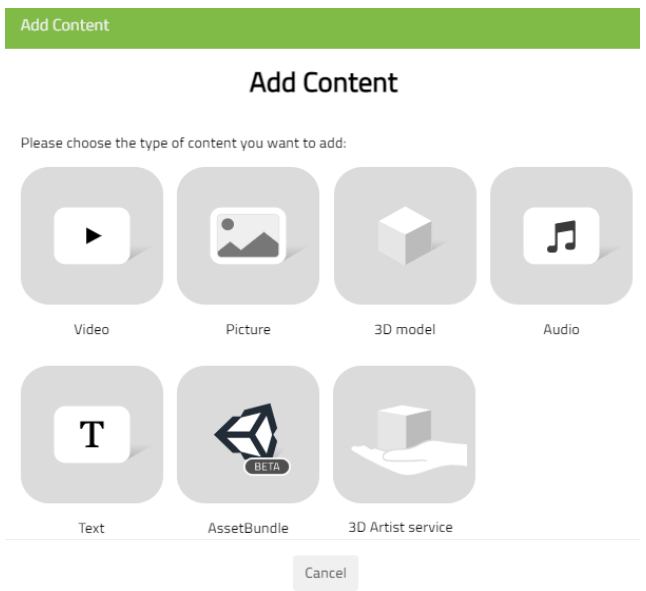

Figure 15. QR section material screen
Step6: In Figure 15, the download process of the developed motherboard model has been performed by selecting the 3D model section. The steps given in Figure 14 on the screen in Figure 16 below have been made and the motherboard model has been loaded in .fbx format.

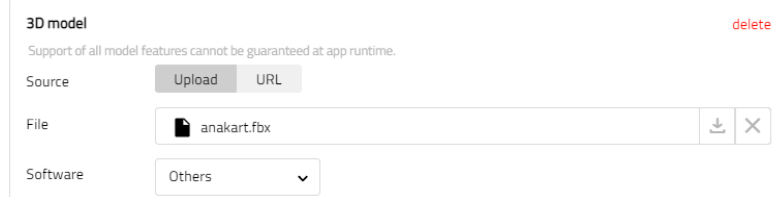

Figure 16. Upload 3D model display

Step7: At the end of the process, the downloaded file was recorded from the screen in Figure 17 and the download process was realized.

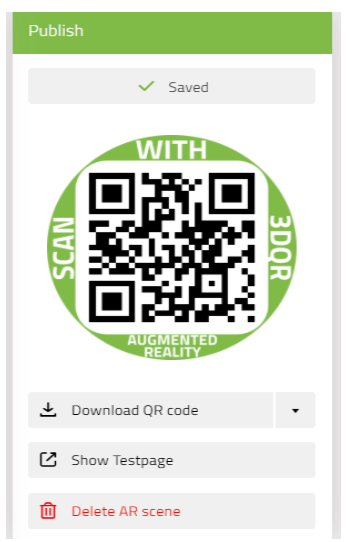

Figure 17. QR recording screen

Step8: The downloaded version of the QR code created in the application is reflected on the screen and shown in Figure 18.

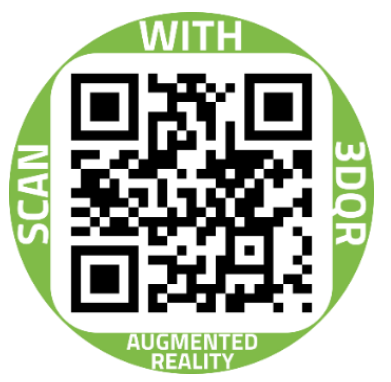

Figure 18. QR code screen

In this study, the display of motherboard components has been carried out using 3DQR technology. With the 3DQR application installed on the mobile device, the images of the QR code on the application were reflected on the screen as seen in Figure 19 and Figure 20.

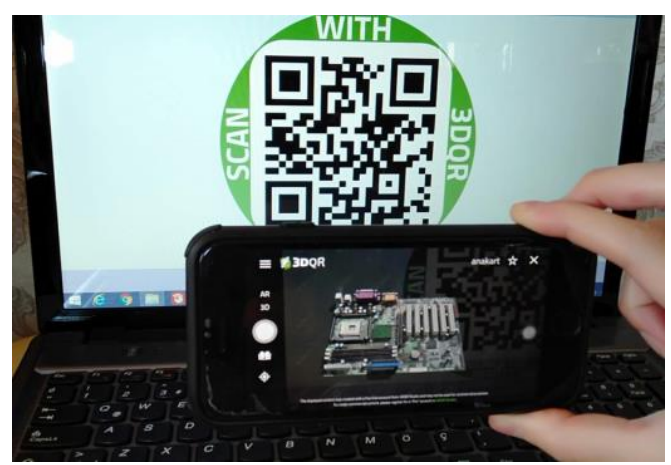

Figure 19. Mobile application screen of the 3D model of the motherboard 1st motherboard 


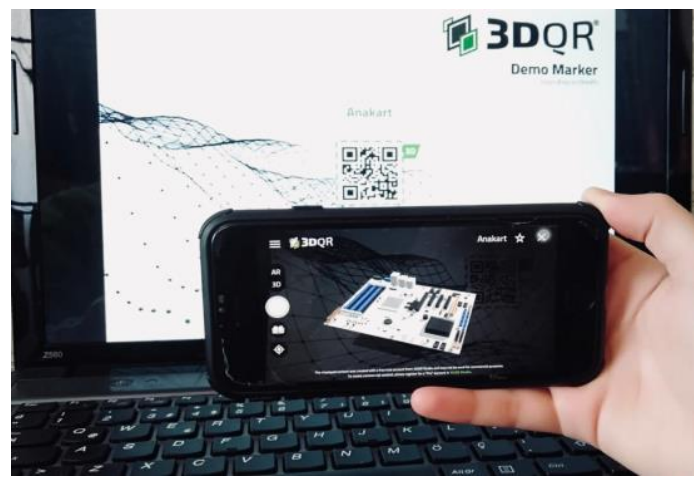

Figure 20. Mobile application screen of the 3D model of the motherboard 1st motherboard

The motherboard shown in Figure 19 has been implemented on the full screen as seen in Figure 21. Then, the names of its components and ports are written as shown in Figure 22 and Figure 23.

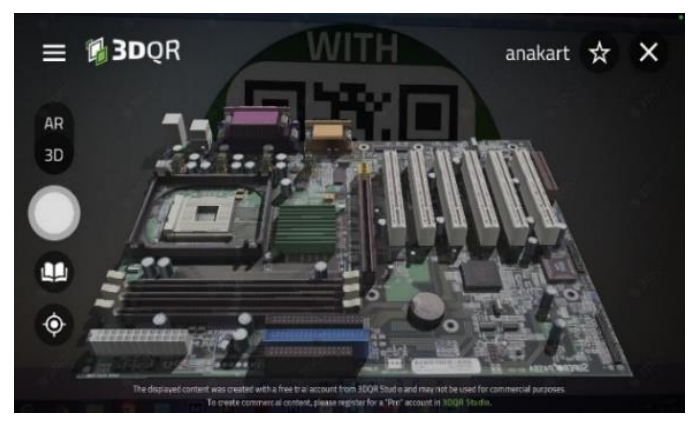

Figure 21. Motherboard 3D model display

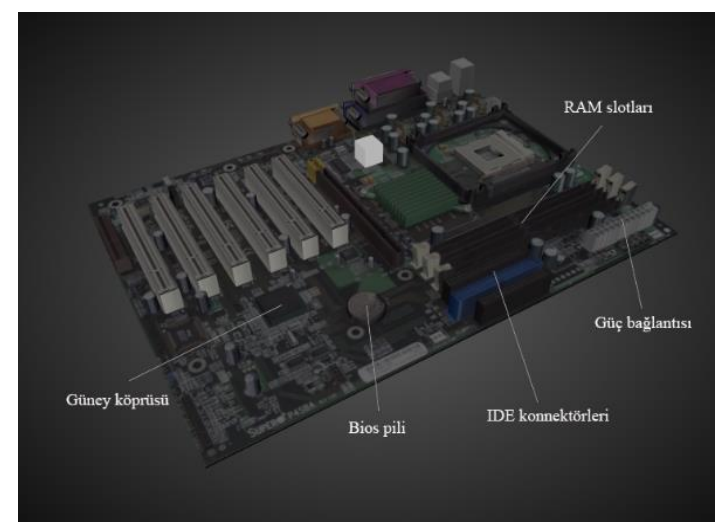

Figure 22. Motherboard 3D model components

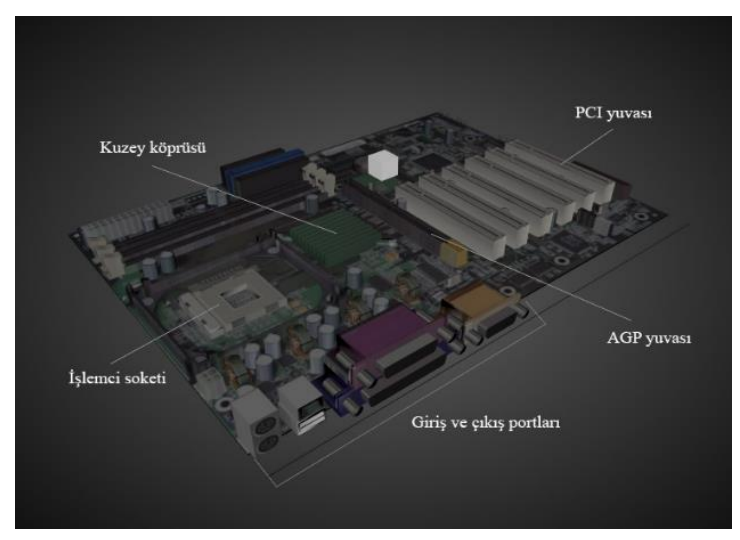

Figure 23. Motherboard 3D model components
When the port names are clicked at the last stage of the application, the explanations described below are displayed and the application is completed.

RAM Slots: RAM, which means random access memory, is lost when the power is cut off. It is known as the storage area where the information of the program that the processors run is temporarily kept. It is the slot in which RAM, the temporary memory unit of the computer, is installed.

Power Connection: A power connection is required in order to provide the necessary power to the computers and to fulfill the functions of the motherboard. These connectors are plugged into the socket on the motherboard and the power supply is connected.

IDE: Connectors that allow devices such as hard disks, optical drives (CD, DVD) to be connected to the motherboard.

Bios Battery: The bios battery on the motherboard allows the computers to keep the time and date settings in their memory.

PCI: PCI slots, which are white and have more than one number, are connected to the network, sound cards, video cards, and modems, allowing connection to the motherboard.

North Bridge: It provides information communication between the graphics card, RAM, and CPU slots.

South Bridge: It is located on the motherboard near parts such as sound card, USB devices, PCI and controls the computer's ports.

AGP: AGP bus is the accelerated graphics port and it is the slot for the computer to plug into the motherboard.

Input and Output Ports: These are the ports that provide data exchange with external hardware units. These ports can be found inside or outside the computer case.

Processor Socket: There are too many pins on the processor. These pins provide the transmission between the motherboard and the processor. The processor must match the motherboard socket and it is placed with the help of the lock on it [19].

\section{Conclusions and Recommendations}

As mentioned before, the application primarily targets middle school, high school, and university students and then other users who have the application. And the main purpose is to teach the motherboard, the components on it, and the ports where these components are installed. The application was started for this exact purpose, but a problem was encountered at this stage. The problem is that there have been hundreds of different motherboards since the first motherboard manufactured in 1982 [20]. For the application, it is necessary to obtain 3D images of all these motherboards and to introduce the components and ports in these images. At this stage, it will take a very long time to obtain 3D images of many different cards. The application had to be revealed and tried as soon as possible in order not to lose its originality compared to the applications made so far. For this reason, the application has been carried out on 2 different motherboards obtained for now and the test phase has started.

During the test phase, first of all, a user from middle school, high school, and university students who were interested in the subject but not knowledgeable was selected, the application was opened and its benefits were observed. Users who use the application have learned that the motherboard, its components, 
and the ports where these components are installed, and they can now remove and install the components on this motherboard as they wish. Thus, even within certain limits, the application has achieved its purpose.

In the next versions of the application, all motherboards manufactured since 1982 should be introduced to the application and the components and ports on these motherboards should also be defined. In this way, the planned goal when starting the implementation will be achieved completely.

Another process that can be done in other versions of the application is to add short videos to the application that show how the motherboard components should be installed in the ports where it will be installed. In this way, the answers to the questions of which component, which port, and how to attach, will be obtained.

\section{References}

[1] Savaş F., 2016, Dijital Dünyanın Gerçekliği, Gerçek Dünyanın Sanallığı Bir Dijital Medya Ürünü Olarak Sanal Gerçeklik, TRT akademi dergisi, ISSN 2149-9446 Cilt 01 Sayı 02 Temmuz 2016 Dijital Medya Sayısı.

[2] Anonim, 2018, Sanal Gerçekliğin Kullanım alanları [online], https://www.hurriyet.com.tr/kelebek-icerikortakliklari/nasil-kolay/sanal-gercekligin-kullanim-alanlari40838877 (Erişim Zamanı: 20.04.2021 - 15.30)

[3] Şimşek İ., Can T., 2019, Yüksek Öğretimde Sanal Gerçeklik Kullanımı ile İlgili Yapılan Araştırmalara Yönelik İçerik Analizi, Folklor/Edebiyat, cilt:25, sayı: 97-1, 2019/1, DOI: 10.22559/folklor.928

[4] Arvin Christopher C. REYES, Neil Patrick A. Del GALLEGO, Jordan Aiko P. DEJA, 2020, Mixed Reality Guidance System for Motherboard Assembly Using Tangible Augmented Reality, ICVARS 2020: Proceedings of the 2020 4th International Conference on Virtual and Augmented Reality Simulations February 2020 Pages1https://doi.org/10.1145/3385378.3385379.

[5] Ahmet Fatih AVCI, Şakir TAŞDEMİR, 2019, Artırılmış ve Sanal Gerçeklik İle Periyodik Cetvel Öğretimi, SelçukTeknik Dergisi, Cilt 18, Sayı:2-2019 ISSN 1302-6178.

[6] Mustafa Sırakaya, Ebru Kılıç Çakmak, 2018, Effects of Augmented Reality on Student Achievement and SelfEfficacy in Vocational Education and Training, International Journal for Research in Vocational Education and Training, 5(1), 1-18. https://doi.org/10.13152/IJRVET.5.1.1

[7] Recep ASLAN, Saffet ERDOĞAN, 2017, 21. Yüzyılda Hekimlik Eğitimi: Sanal Gerçeklik, Artırılmış Gerçeklik, Hologram, Kocatepe Veterinary Journal Y1l: 2017Cilt: 10Sayı: 3ISSN: 2147-6853 / 2147-6853Sayfa Aralığı: 204 212.

[8] Igor D.D. Curcio, Anna Dipace , Anita Norlund , 2016, Virtual realities and education, REM - Research on Education and Media Vol. 8, N. 2, Year 2016 ISSN: 20370830 - DOI: 10.1515/rem-2016-0019

[9] Mustafa Sırakaya, 2016, Ahi Evran Üniversitesi Kırşehir Eğitim Fakültesi Dergisi (KEFAD) Cilt 17, Sayı 3, Aralık 2016, Sayfa 301-316.

[10] Tansel Tepe, Devkan Kaleci, Hakan Tüzün, 2016 Eğitim Teknolojilerinde Yeni Eğilimler: Sanal Gerçeklik Uygulamalar, 10th International Computer and Instructional Technologies Symposium (ICITS).

[11] Giles Westerfield, Antonija Mitrovic \& Mark Billinghurst, 2015, Intelligent Augmented Reality Training for
Motherboard Assembly, International Journal of Artificial Intelligence in Education volume 25, pages157-172(2015).

[12] H. Hakan Çetinkaya, Muammer Akçay, 2013, Eğitim Ortamlarında Arttırılmış Gerçeklik Uygulamaları, Akademik Bilişim 2013 - XV. Akademik Bilişim Konferans1 Bildirileri 23-25 Ocak 2013 - Akdeniz Üniversitesi, Antalya.

[13] Erkan BAYRAKTAR, Fatih KALELİ,2007, Sanal Gerçeklik ve Uygulama Alanları, Akademik Bilişim 2007 Dumlupınar Üniversitesi, Kütahya, 31 Ocak-2 Şubat 2007FLEXChip Signal Processor (MC68175/D), Motorola, 1996.

[14] Şahin KARASAR, 2004, Eğitimde Yeni İlitişim Teknolojileri-İnternet ve Sanal Yüksek Eğitim-, Karasar, Ş. (2004). Eğitimde yeni ilitişim teknolojileri-internet ve sanal yüksek eğitim-. The Turkish Online Journal of Educational Technology. 3(4), s. 117-125.

[15] Bülent ÇAVAŞ, Pınar HUYUGÜZEL ÇAVAŞ, Bilge TAŞKIN CAN, 2004, Eğitimde Sanal Gerçeklik, The Turkish Online Journal of Educational Technology - TOJET October 2004, ISSN: 1303-6521, volume 3, Issue 4, Article 15R. E. Sorace, V. S. Reinhardt, and S. A. Vaughn, "Highspeed digital-to-RF converter," U.S. Patent 5668 842, Sept. 16, 1997.

[16] Dr. Şahin KARASAR, 1999, İnternet Ortamında Eğitim, Kuram ve Uygulamada Eğitim Yönetimi Dergisi, 1999, Say1 18 , cilt 18, Sayfa $145-168$.

[17] K. M. BAIRD, W. BARFIELD, 1999, Evaluating the Effectiveness of Augmented Reality Displays for a Manual Assembly Task, Virtual Reality December 1999 https://doi.org/10.1007/BF01421808

[18] Yrd.Doç. Dr. Servet Bayram, 1999, Eğitimde Sanal Gerçeklik Uygulamaları, M.Ü. Atatürk Eğitim Fakültesi Eğitim Bilimleri Dergisi Y1l: 1999, Say1: 11, Sayfa: 49-54.

[19] Akkaya Ç., 2017, Anakartlar [online], https://caglaakkaya.wordpress.com/2017/11/28/anakartlar/ (Access Time: 19.05.2021 - 15.30)

[20] Pixel H., 2012, İlk Anakart [online], https://www.technopat.net/sosyal/konu/ilk-anakart.18454/ (Erişim Zamanı: 26.04.2021 - 15.35). 